\title{
DETERMINING DENSITY AND MOISTURE CONTENT OF THE EUROPEAN BEECH (Fagus sylvatica L.) COARSE WOODY DEBRIS FROM THE SECONDARY VIRGIN FOREST RAJHENAVSKI ROG UGOTAVLJANJE GOSTOTE IN VSEBNOSTI VLAGE V VELIKIH LESNIH OSTANKIH BUKVE (Fagus sylvatica L.) IZ PRAGOZDNEGA REZERVATA RAJHENAVSKI ROG
}

\author{
Domen FINŽGAR ${ }^{1}$, Matej RUPEL ${ }^{2}$, Miha HUMAR ${ }^{3}$, Hojka KRAIGHER ${ }^{4}$ \\ (1) Ulica nadgoriških borcev 15, 1000 Ljubljana, Slovenia, domen.finzgar@gmail.com \\ (2) Gozdarski inštitut Slovenije, Večna pot 2,1000 Ljubljana, matej.rupel@gozdis.si \\ (3) Biotehniška fakulteta, Oddelek za lesarstvo, Rožna dolina Cesta VIII/34, 1000 Ljubljana, Slovenia, miha.humar@bf.uni-lj.si \\ (4) Gozdarski inštitut Slovenije, Večna pot 2,1000 Ljubljana, Slovenia, hojka.kraigher@gozdis.si
}

\begin{abstract}
Measuring density of wood samples with mercury volumemeter is a standard throughout the world. To find out the reliability of another less toxic density measuring technique, samples were measured in a mercury medium and in a water medium as well. This study is a revision of the previously published results (Finžgar et al., 2013), since the determination of decay phases was questionable and correct results are presented here. New data is also presented herewith. For water measurements, the MSA 323S scale (Sartorius, Germany) with YDK01 Density Determination Kit (Sartorius, Germany) was used for the first time in our labs. We measured density of coarse woody debris from the secondary virgin forest reserve Rajhenavski Rog, Slovenia. Results of the two methods employed were not comparable due to different density definitions. Also, lower densities in higher decay phases were not detected, although expected. Nevertheless, the scale MSA 323S proved to be a reliable method of measuring wood sample density in water. However, some optimizations will have to be considered in the future.
\end{abstract}

Key words: Breuil volume-meter, decay phase, density definition, Sartorius MSA 323S, mercury, water

\begin{abstract}
IZVLEČEK
V Sloveniji in po svetu se je merjenje gostote v živosrebrnem mediju obravnavalo kot standardni postopek. Merjenje gostot v živem srebru je problematično zaradi zahtev Evropske unije po umiku te nevarne snovi iz človekovega okolja. Zato so meritve gostot v tej raziskavi potekale $\mathrm{v}$ različnih medijih z namenom iskanja alternativnega postopka. Ta raziskava revidira že objavljene rezultate (Finžgar in sod., 2013), saj je bila takratna določitev nekaterih stopenj razkroja vprašljiva. Prav tako so predstavljeni nekateri povsem novi rezultati. Tehtnica MSA 323S z dodatkom za merjenje gostot YDK01 (Sartorius, Nemčija) je bila v laboratoriju Gozdarskega inštituta Slovenije uporabljena prvič. Merili smo gostoto vzorcev velikih lesnih ostankov iz pragozdnega rezervata Rajhenavski Rog v vodnem in živosrebrnem mediju. Rezultati med seboj niso bili primerljivi, saj so bile uporabljene različne definicije gostote. Prav tako nismo zaznali izrazito manjših gostot $\mathrm{v}$ višjih stopnjah razkroja. Z našo raziskavo potrjujemo, da gostota lesa $\mathrm{z}$ razkrojem pada. Merilna tehtnica MSA 323S z dodatkom za merjenje gostot se je izkazala za izjemno hitro in preprosto metodo merjenja gostot lesa, čeprav bo treba v prihodnjih raziskavah postopek optimizirati.
\end{abstract}

Ključne besede: Breuilov volumometer, definicija gostote, Sartorius MSA 323S, stopnja razkroja, voda, živo srebro

GDK 114.122:537--017(497.4Rajhenavski Rog)(045)=111--017 Prispelo / Received: 30.032014

Sprejeto / Accepted: 15. 05. 2014

\section{INTRODUCTION}

1 UVOD

During the culmination of the trees' mean annual increment, trees function as carbon sinks. Later on, during the decomposition of the trees, they function as a carbon source (Nijnik, 2010). It is therefore necessary to understand the decomposition of wood in order to understand the carbon dynamics. Coarse woody debris (CWD) in climax forests ex- plains much of these dynamics and a large number of studies have tried testing this by examining CWD volumes in different forest ecosystems. However, the estimates vary significantly not only because they are obtained in different forest ecosystems, but also because studies use different plot sizes, mathematical formulas for estimating volumes, sampling methods and biomass to volume conversions. The latter is considered especially problematic, since the density 
changes during the decay, while the volume remains relatively unchanged (Jonsson and Sitonen, 2012). The decomposition of CWD is somewhat predictable. As time passes, the dead tree loses mass, volume and density. The exponential model presented with the formula below is often used to explain this process:

$$
\mathrm{Y}_{\mathrm{t}}=\mathrm{Y}_{0} \mathrm{e}^{-\mathrm{kt}}
$$

where $\mathrm{Y}_{\mathrm{t}}$ represents the density in time $t, \mathrm{Y}_{0}$ is the original density, and $k$ the decay coefficient. This model is indeed a convenient tool to compare decay rates, but has certain drawbacks. It simplifies the decay process by defining decomposition rates as a constant through time. New models will be needed to fully capture the decay processes (Stokland and Siitonen, 2012).

Different wood density definitions can also be the source of bias. There are three common wood density definitions used in literature: absolute density (oven dry sample mass, divided by the volume of oven dry samples), basic density (oven dry sample mass, divided by the maximum sample volume) and green density (mass of the sample when green, divided by the volume of a fresh sample) (Wagenführ, 1996; Torelli, 1998; Walker, 2006).

In the case of this study, the important definitions are not only the ones mentioned above but saturated density as well (mass of the maximum saturated sample, divided by the maximum volume). The mentioned definitions are only roughly comparable, therefore the comparison of studies using different definitions is statistically questionable (Wagenführ, 1996).

Studies have shown that the most useful descriptor for density is basic density (Olesen, 1971; Usta, 2003; Walker, 2006), since the parameters (mass and volume) have constant and reproducible values (Walker, 2006) and the variability of obtained values is lower, if we soak the samples in water for a sufficient period of time (Ericson, 1966).

In the previous study in which the importance of CWD for carbon dynamics and biodiversity in Slovenian forests was described, absolute density was used. It was measured by the Breuil mercury volume-meter (Kraigher et al., 2002).

The European Commission and the Council have first restricted the sale of measuring devices containing mercury for the general public with the Regulation No. 1907/2006. A further amendment by the Commission has restricted several measuring devices containing mercury (including pycnometers), used in industrial and professional (including healthcare) applications. This amendment should already have been in action since April 2013, but its implementation was delayed. The regulation came into force on $10^{\text {th }}$ of April 2014 (Regulation No. 847/2012).

Measuring densities with mercury and water medium volume-meters are now standards in forestry research. However, the ban of mercury with Regulation No. 847/2012 is forcing researchers to find alternatives for mercury based density measurements. Although some studies have shown that mercury based measurements provide better accuracy (Plickat, 1961), later studies argued this fact. It is now generally accepted that, provided the right sample sizes, differences of accuracy between the mentioned mediums are almost irrelevant (Olsen, 1971). Studies discussing different density definitions and the methods of measuring wood densities used samples of healthy, non-decayed wood, cut to known, constant, square-shaped dimensions. Of course, these requirements cannot be fulfilled when dealing with decayed wood samples that have lost their structural strength. These samples are often an important part of the CWD studies, where wood is always in different stages of decay (Kraigher et al., 202).

The aim of this study is to define the methodology for CWD density measurements in water medium for later standardization purposes. Changes of methodology from mercury to water medium are necessary not only to fulfil the current EU mercury policy, but to reduce the impact of mercury on human health. In order to compare the results of this study with the previous findings (2002), we tried to collect and measure the samples in the same way as described in Kraigher et al., 2002. This means that the measurements were made in water medium and in the Breuil mercury volume-meter.

Since the CWD samples were all oven-dried, we easily calculated the moisture content along with the density measurements. As with the density loss, the moisture content during the decay is quite predictable as well. Because of the reduced desiccation caused by the soil moisture and since the decomposition process itself produces water as an end-product, the moisture content during the decay steadily increases (Stokland and Siitonen, 2012).

\section{MATERIALS AND METHODS}

2 MATERIAL IN METODE

\subsection{Secondary virgin forest reserve Rajhenavski}

\subsection{Pragozdni rezervat Rajhenavski rog}

The secondary virgin forest reserve Rajhenavski Rog was first mentioned as a forest reserve by Leopold Hufnagl in 1904, and later on, in 1957, the first inventory of stands in this 51.4 ha area was conducted by Derbiš 
(Derbiš, 1957). In 1985, Prof. Dr. Mlinšek established the first permanent research plots (Bončina, 1999). Parent material at the site is limestone, soil is described as eutric cambisols and rendzic leptosols, variation in depth is present due to the karst geomorphology. The reserve belongs to the Dinaric silver fir-beech forest OmphalodoFagetum (Treg. 1957 corr. Puncer 1980) with different sub-associations (Hartman, 1999; Kraigher et al., 2002).

For the purpose of this study, we used the sampled area as set in the NAT-MAN project in 2002. It covers the south border of the secondary virgin forest reserve Rajhenavski Rog, with a total of 3.20 ha (Ódor et al., 2006; Kraigher et al., 2002).

\subsection{Determining decay phases of coarse woody debris}

2.2 Določevanje stopenj razgradnje velikih lesnih ostankov

The on-site decay phase description of each individual piece of CWD from European beech (Fagus sylvatica L.) was determined with the descriptive sixstage classification method described in Kraigher et al. (2002) (Table 1). To ensure objectivity, the determination was done in three members group in 2012 and 2013. Partial results of CWD densities, published in Finžgar et al. (2013), showed that the determination of earlier stages of decay (first and second) might have

Table 1: Descriptive, six class determination method for decomposing coarse woody debris (Kraigher et al., 2002) been mistaken. One last revision of determination was therefore made on 9. 7. 2013.

\subsection{Sampling methods}

\subsection{Vzorčenje}

The first sampling of the selected CWD was carried out in November 2011, while further measurements were done throughout 2012.

Samples from CWD were collected using a drill, both from stumps and trunks. We mainly chose the same CWD as in 2002. During that research, single pieces of CWD were tagged at site and some characteristics described (e. g. diameter at breast height (DBH), length, moss cover ...) (Kraigher et al., 2002). In 2012, samples were mostly collected from the first five decay stages. It is impossible to determine density when wood material is highly degraded in stage six. Owing to the different diameters of drills and use of different drilling machines, the samples were smaller compared to the study done in 2002. The collection of samples was implemented by M. Rupel, who was responsible for sampling in 2002 as well (Kraigher et al., 2002). From the drilled wood material, the sum of 207 samples from 17 individual pieces of CWD was randomly collected for the density measurements in mercury medium. For the measurements in water medium, the sum of samples was 163 from 15 CWD individuals.

Preglednica 1: Šeststopenjska lestvica faz razkroja

\begin{tabular}{|c|c|c|c|c|c|}
\hline $\begin{array}{l}\text { Decay Phase } \\
\text { Faze razkroja }\end{array}$ & $\begin{array}{l}\text { Bark } \\
\text { Skorja }\end{array}$ & $\begin{array}{l}\text { Twigs and shoots } \\
\text { Veje in poganjki }\end{array}$ & $\begin{array}{l}\text { Softness } \\
\text { Trdota lesa }\end{array}$ & $\begin{array}{l}\text { Surface } \\
\text { Površina }\end{array}$ & $\begin{array}{l}\text { Shape } \\
\text { Oblika }\end{array}$ \\
\hline 1 & $\begin{array}{c}\text { Intact or missing only } \\
\text { in small patches, more } \\
\text { than } 50 \% \\
\text { Manjka največ } 50 \%\end{array}$ & $\begin{array}{l}\text { Present } \\
\text { Prisotni }\end{array}$ & $\begin{array}{c}\text { Hard or knife penetration 1-2 } \\
\text { mm } \\
\text { Trd, nož se zapiči največ } 2 \\
\text { mm globoko }\end{array}$ & $\begin{array}{l}\text { Covered by bark, outline } \\
\text { intact } \\
\text { Prekrita s skorjo, površina } \\
\text { nedotaknjena }\end{array}$ & $\begin{array}{l}\text { Circular } \\
\text { Krožna }\end{array}$ \\
\hline 2 & $\begin{array}{l}\text { Missing or less than } \\
50 \% \\
\text { Manjka več kot } 50 \%\end{array}$ & $\begin{array}{c}\text { Only branches }(>3 \mathrm{~cm} \text { in } \\
\text { diameter) present } \\
\text { Prisotne samo veje nad } \\
3 \mathrm{~cm}\end{array}$ & $\begin{array}{l}\text { Hard or knife penetration less } \\
\text { than } 1 \mathrm{~cm} \\
\text { Trd, nož največ } 1 \mathrm{~cm} \text { globoko }\end{array}$ & $\begin{array}{l}\text { Smooth, outline intact } \\
\text { Gladka, površina nedota- } \\
\text { knjena }\end{array}$ & $\begin{array}{l}\text { Circular } \\
\text { Krožna }\end{array}$ \\
\hline 3 & $\begin{array}{l}\text { Missing } \\
\text { Manjka }\end{array}$ & $\begin{array}{l}\text { Missing } \\
\text { Manjkajo }\end{array}$ & $\begin{array}{c}\text { Becoming soft, knife penetra- } \\
\text { tion } 1-5 \mathrm{~cm} \\
\text { Postaja mehak, nož } 1-5 \mathrm{~cm} \\
\text { globoko }\end{array}$ & $\begin{array}{c}\text { Smooth or crevices present, } \\
\text { outline intact } \\
\text { Gladka ali razpokana, površi- } \\
\text { na nedotaknjena }\end{array}$ & $\begin{array}{l}\text { Circular } \\
\text { Krožna }\end{array}$ \\
\hline 4 & $\begin{array}{l}\text { Missing } \\
\text { Manjka }\end{array}$ & $\begin{array}{l}\text { Missing } \\
\text { Manjkajo }\end{array}$ & $\begin{array}{l}\text { Soft, knife penetration more } \\
\text { than } 5 \mathrm{~cm} \\
\text { Mehak, nož čez } 5 \mathrm{~cm} \text { globoko }\end{array}$ & $\begin{array}{l}\text { Large crevices, small pieces } \\
\text { missing, outline intact } \\
\text { Razpokana, manjši deli manj- } \\
\text { kajo, površina nedotaknjena }\end{array}$ & $\begin{array}{l}\text { Circular or eliptic } \\
\text { Krožna ali ovalna }\end{array}$ \\
\hline 5 & $\begin{array}{l}\text { Missing } \\
\text { Manjka }\end{array}$ & $\begin{array}{l}\text { Missing } \\
\text { Manjkajo }\end{array}$ & $\begin{array}{l}\text { Soft, knife penetration more } \\
\text { than } 5 \mathrm{~cm} \\
\text { Mehak, nož čez } 5 \mathrm{~cm} \text { globoko }\end{array}$ & $\begin{array}{c}\text { Large pieces missing, outline } \\
\text { partly deformed } \\
\text { Veliki deli manjkajo, površina } \\
\text { spremenjena } \\
\end{array}$ & $\begin{array}{l}\text { Flat elliptical } \\
\text { Plosko ovalna }\end{array}$ \\
\hline 6 & $\begin{array}{l}\text { Missing } \\
\text { Manjka }\end{array}$ & $\begin{array}{l}\text { Missing } \\
\text { Manjkajo }\end{array}$ & $\begin{array}{l}\text { Soft, partly reduced to mould, } \\
\text { only core of wood } \\
\text { Mehak, samo ostanki lesa }\end{array}$ & $\begin{array}{l}\text { Outline hard to define } \\
\text { Površina težko določljiva }\end{array}$ & $\begin{array}{l}\text { Flat elliptical, } \\
\text { covered by soil } \\
\text { Plosko ovalna, } \\
\text { prekrita z zemljo }\end{array}$ \\
\hline
\end{tabular}




\subsection{Measuring cwd density and moisture con- tent}

2.4 Merjenje gostote in vsebnosti vlage v VLO

Absolute density was measured in mercury, while basic density and saturated density (the maximum moisture sample mass, divided by the maximum volume of samples) were measured in water.

In the laboratory, irregularly shaped drilled material (from $181.6 \mathrm{~g}-1266.8 \mathrm{~g}$, median = $373.3 \mathrm{~g}$ ) was weighed $( \pm 0.0001 \mathrm{~g})$, then dried on $105 \pm 2{ }^{\circ} \mathrm{C}$ in 24 hours, cooled down to room temperature in a desiccator and weighed again for the determination of moisture content.

From this material, smaller samples (from $0.8 \mathrm{~cm}^{3}$ - $15 \mathrm{~cm}^{3}$, median $=4.2 \mathrm{~cm}^{3}$ ) were collected and submerged into mercury for density measurements, using the Breuil volume-meter $\left( \pm 0.1 \mathrm{~cm}^{3}\right)$. After the measurements, some of the mercury remained inside the samples' pores, therefore those samples could not be used for the water measurements as well. They were disposed accordingly to safety regulations.

Although samples for the submersion into the water were collected from the same drilled material, it is necessary to emphasize the fact that the wood decay, even from the same drilled material, is very inhomogeneous. Samples were chosen to best represent the average characteristics of the determined decay class, although this is a subjective process (Figure 1).

The chosen samples were again dried at $105 \pm 2^{\circ} \mathrm{C}$ in 24 hours, cooled down to the room temperature in a desiccator and weighted. Thereupon they were submerged into grade 1 water (ISO 3696) and transferred into the vacuum-pressure chamber (protocol: $10 \mathrm{~min}$ - 200 mbar, 30 min - 9 bar, 10 min - 200 mbar).

After soaking, the surplus water was removed with a damp cloth. As this can lead to large systematic errors, it could be easily estimated by sight whether the sample was too wet. The surface of the sample should be mat, without glister. If fingers get humid when touching the sample, the sample is still too wet (Olesen, 1971).

After the removal of the surplus water, the density measurements were carried out on MSA 323S scale (Sartorius, Germany) with YDK01 Density Determination Kit (Sartorius, Germany). Because this was a pilot usage of the mentioned scale, test measurements of eight European birch wood samples of known dimensions $(0.7 \times 1.0 \times 3.0 \mathrm{~cm})$ were conducted. Besides, the measurements were carried out based on several studies focusing on density measurements in water medium (Vintila, 1939, Holz and Plickat, 1961, von Wedel, 1962, Ericson, 1966, Henrichs and Lassen, 1970, Olesen, 1971, Williamson and Wiemann, 2010).

After the revision of decay phases determined in Finžgar et al., 2013, some decay stages lacked wood samples to perform statistical analysis. Therefore additional measurements were made to get the minimal of 20 samples per decay phase.

When using the water scale, specific gravity of the sample in water medium is constantly changing, therefore some deviation from initially measured mass was expected. Scale software calculates density from the next formula:

$$
\begin{aligned}
& \rho=\frac{W(a) * \rho(f l)}{W(a)-W(f l)} \\
& W(a)=\text { mass outside the medium } \\
& W(f l)=\text { relative mass in the medium } \\
& \rho(f l)=\text { water density }
\end{aligned}
$$

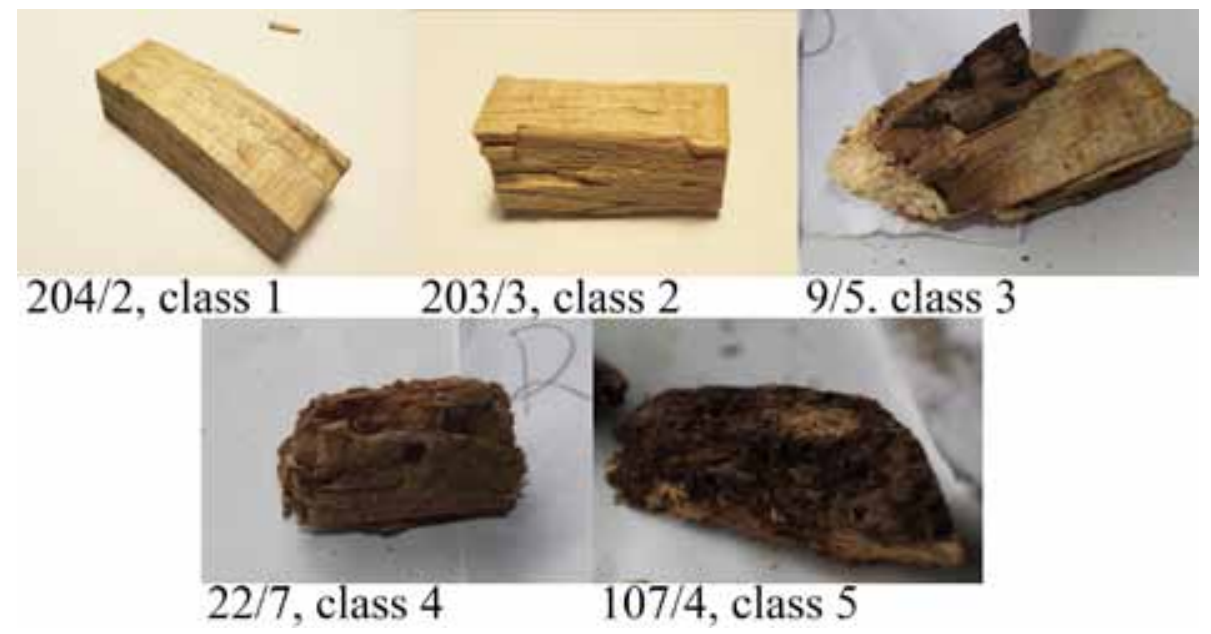

Fig. 1: Examples of samples, chosen for the density measurements. They are labelled with ID and decay phase, separated by a comma.
Slika 1: Primeri vzorcev, na katerih so bile opravljene meritve gostot. Označeni so z oznako ID in fazo razkroja, ločeno z vejico. 
This can lead to some deviations from the measured and calculated saturated and basic density.

\subsection{Decay model evaluation}

\subsection{Ocena modela razkroja $v$ času}

Determining the decay class from the same CWD as in Kraigher et al. (2002) allowed us to evaluate the model that was describing decay rate in time after the death of CWD. For this model, exponential function was used, where age-since-death was determined by dendrochronological analysis, and decay class was the dependant variable (Kraigher et al., 2002). After obtaining the model values for age-since-death, we added additional 11 years (difference between determining decay classes in 2001 and 2012) to these values. We than compared the newly gained values with the expected values in the model.

\subsection{Statistical analysis}

\subsection{Statistična analiza}

Statistical analysis and plots were made in Microsoft Excel 2003, IBM SPSS statistics 19 and R Studio. Analysis of variance (ANOVA) could not be used, as the distribution was not normal (using normal probability plot graphic method). Therefore the Kruskal-Wallis nonparametric test was used. The tested null hypothesis stated: Samples from different decay classes are in fact from the same class. For the same reason - lack of normality in data distribution (un-normal distribution), the Mann-Whitney U nonparametric test was used to compare means between classes 3 and 4 .
For both tests, the confidence level was 0.95. As both tests compare median values, boxplot diagrams showing median values were used.

\section{RESULTS AND DISCUSSION}

\section{REZULTATI IN RAZPRAVA}

Results of this study are densities measured in water and mercury medium, as well as moisture content of different decay stages. Since the unrevised results discussed here were already published in Finžgar et al. (2013), we will present only the results of revised measurements and newly measured data.

Moisture content of wood is usually defined as the weight of water in wood expressed as a fraction of weight of the oven-dry wood (Simpson, 2010). As seen from Figure 2, moisture content, as expected, increases with the progress of decay. However, the moisture content is still lower in the higher classes of decay, compared with results in Kraigher et al. (2002). We explain this with different methods of measuring moisture content used. In 2002, moisture was measured for individual small wood samples (10 g - $15 \mathrm{~g})$, while in this study moisture content was measured directly from the collected drilled material, therefore handling samples with a higher mass $(\approx 373 \mathrm{~g})$. Secondly, wood is a highly heterogeneous material, while the decayed wood is exponentially even more heterogeneous (Kraigher et al., 2002). Thirdly, results also indicate that samples in both studies were not taken in the same weather conditions. Lower variability in decay class 6 may be due to the lower number of drills from this class, since they were not used in further analysis.

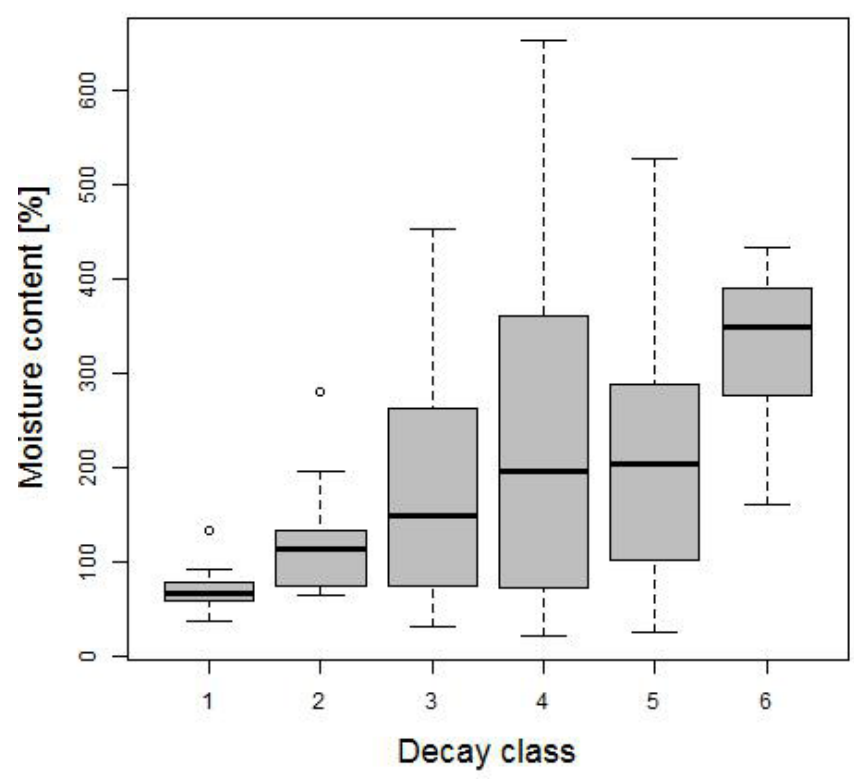

Fig. 2: Moisture content of the drilled material

Slika 2: Vsebnost vlage izvrtkov posamezne stopnje razgradnje 
Table 2: Difference between the calculated volume and the volume measured with MSA 323S for eight test samples
Preglednica 2: Razlike volumnov, merjenih z MSA 323S (merjen volumen $\left(\mathrm{H}_{2} \mathrm{O}\right)$, in izračunanih volumnov osmih testnih vzorcev

\begin{tabular}{|c|c|c|c|c|}
\hline $\begin{array}{c}\text { Sample ID } \\
\text { ID vzorca }\end{array}$ & $\begin{array}{c}\text { Mass [g] } \\
\text { Masa }[\mathrm{g}]\end{array}$ & $\begin{array}{c}\text { Calculated volume }\left[\mathrm{cm}^{3}\right] \\
\text { Izračunani volumen }\left[\mathbf{c m}^{3}\right]\end{array}$ & $\begin{array}{c}\text { Measured volume }\left[\mathrm{cm}^{3}\right] \\
\text { Merjeni volumen }\left(\mathbf{H}_{2} \mathbf{O}\right)\left[\mathbf{c m}^{3}\right]\end{array}$ & $\begin{array}{c}\text { Difference [\%] } \\
\text { Razlika v procentih }\end{array}$ \\
\hline 1 & 2.687 & 5.512 & 5.452 & 1.10 \\
\hline 2 & 2.9069 & 5.596 & 5.450 & 2.69 \\
\hline 3 & 2.9783 & 5.621 & 5.515 & 1.92 \\
\hline 4 & 3.0915 & 5.527 & 5.403 & 2.30 \\
\hline 5 & 2.9684 & 5.556 & 5.433 & 2.27 \\
\hline 6 & 3.1965 & 5.580 & 5.444 & 3.50 \\
\hline 7 & 2.7725 & 5.418 & 5.223 & 1.61 \\
\hline 8 & 2.8079 & 5.502 & 5.415 & 2.26 \\
\hline
\end{tabular}

Moisture measurements of eight European beech samples with known dimensions are given in Table 2 . Less than $3 \%$ of the difference from calculated volume is expected, since calculations did not predict any concavity of the samples. Therefore, based on the results, MSA 323S seemed appropriate for further samples analysis. However, additional tests of the scale should be made in the future in order to statistically justify its use.

Average values of density measurements from different decay classes are presented in Table 3. Values are comparable with those from 2002 (Kraigher et al., 2002), however, standard deviation is higher. This means that some optimization could have been made regarding sampling and the transportation methods of samples from the site to the laboratory. Measurements of decay classes 1 and 2 in mercury medium were excluded from results (Figure 3), since the revision on 9. 7. 2013 showed that certain decay classes were questionably determined.

Median value from the calculated and measured saturated densities was $0.0012 \mathrm{~g} / \mathrm{cm}^{3}$ and the maximum deviation was $0.7456 \mathrm{~g} / \mathrm{cm}^{3}$. We assume that the maximum deviation is the result of an operational error, since the next maximal value was only $0.0023 \mathrm{~g} /$ $\mathrm{cm}^{3}$. The deviations regarding basic densities are similar. Therefore we can conclude that these errors, which may occur due to the differences between the calculated and the measured values, are insignificant.

Results from Table 3, Figure 4 and Figure 5 show the decline of density during the decay process. The only exception is the decay class 5 where shown densities are considerably high. The results from saturated den-

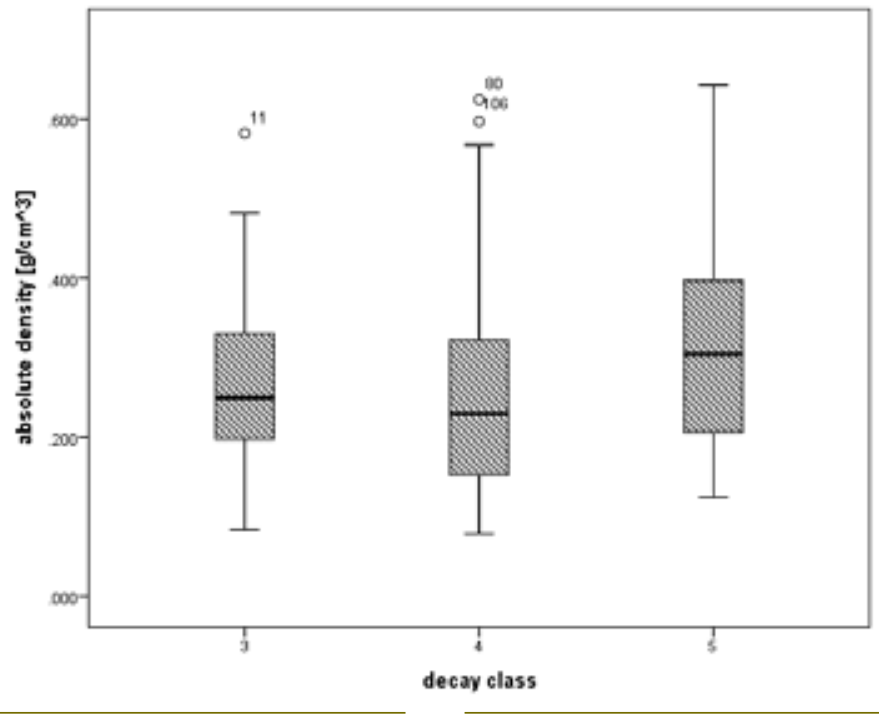

Fig. 3: Box plot diagram showing the absolute densities, measured in the mercury medium, of the decay phases 3-5. Both the presence of outliers and high deviations from the median indicate high variability of the decayed samples. This is a revised figure from Finžgar et al., 2013; no additional measurements were made.

Slika 3: Diagram box plot, ki prikazuje vrednosti absolutnih gostot, merjenih v živem srebru, znotraj faz razkroja 3-5. Osamelci in visoki odkloni od mediane nakazujejo veliko variabilnost znotraj posamezne stopnje razgradnje. Slika prikazuje revidirane vrednosti iz Finžgar et al., 2013, novih meritev gostote ni bilo. 
Table 3: Average values and standard deviations (SD) for the different decay classes and density definitions. In brackets, the number of measured samples is noted. Basic density and saturated density were measured in water medium $\left(\mathrm{H}_{2} \mathrm{O}\right)$, while absolute density was measured in mercury medium ( $\mathrm{Hg}$ ).
Preglednica 3: Povprečne vrednosti in standardni odklon (SD) različnih gostot po fazah razkroja. V oklepajih je zapisano število vzorcev, pri katerih je bila izmerjena gostota. Osnovna gostota (basic density) in nasičena gostota (saturated density) sta bili izmerjeni v vodnem mediju $\left(\mathrm{H}_{2} 0\right)$, absolutna gostota pa v živosrebrnem mediju (Hg).

\begin{tabular}{|c|c|c|c|c|c|c|}
\hline & \multicolumn{6}{|c|}{ Average values of different density definitions [g/cm3]/ Povprečne vrednosti različnih gostot $\left[g / \mathrm{cm}^{3}\right]$} \\
\hline $\begin{array}{c}\text { Decay class } \\
\text { No. of samples }\end{array}$ & $\begin{array}{c}\text { Basic density } \\
(\mathrm{H}, 0)\end{array}$ & SD Basic density & $\begin{array}{c}\text { Saturated density } \\
(\mathrm{H}, 0)\end{array}$ & $\begin{array}{c}\text { SD Saturated } \\
\text { density }\end{array}$ & $\begin{array}{c}\text { Absolute density } \\
(\mathrm{Hg})\end{array}$ & $\begin{array}{c}\text { SD Absolute } \\
\text { density }\end{array}$ \\
\hline $\begin{array}{c}1 \\
\mathrm{~B}(39), \mathrm{S}(40), \mathrm{A}(0)\end{array}$ & 0.552 & 0.129 & 1.131 & 0.109 & & \\
\hline $\begin{array}{c}2 \\
\mathrm{~B}(30), \mathrm{S}(30), \mathrm{A}(0)\end{array}$ & 0.417 & 0.149 & 1.054 & 0.129 & & \\
\hline $\begin{array}{c}3 \\
\mathrm{~B}(21), \mathrm{S}(20), \mathrm{A}(38)\end{array}$ & 0.201 & 0.084 & 0.909 & 0.217 & 0.262 & 0.116 \\
\hline $\begin{array}{c}4 \\
\mathrm{~B}(46), \mathrm{S}(48), \mathrm{A}(96)\end{array}$ & 0.209 & 0.114 & 0.833 & 0.282 & 0.250 & 0.120 \\
\hline $\begin{array}{c}5 \\
\mathrm{~B}(27), \mathrm{S}(27), \mathrm{A}(54)\end{array}$ & 0.282 & 0.103 & 0.780 & 0.2550 & 0.322 & 0.136 \\
\hline
\end{tabular}

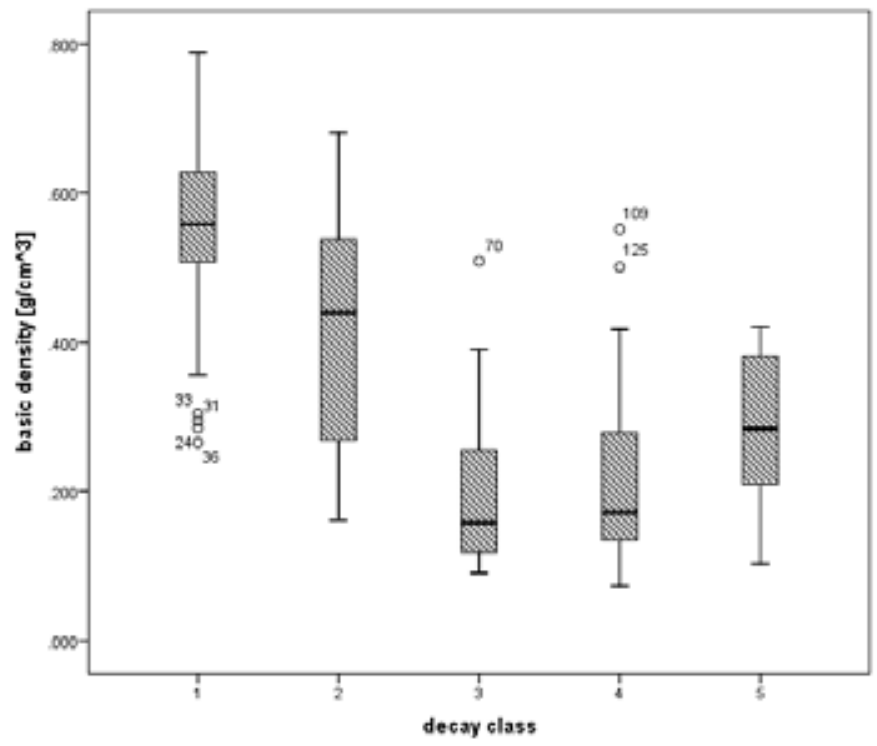

Fig. 4: Box plot diagram showing the basic density values, measured in the water medium by decay class (1-5). Both the presence of outliers and high deviations from the median indicate high variability of the decayed samples. New measurements are included, and revised data from Finžgar et al., 2013 are presented.

Table 4: P (sig.) values of the Kruskal-Wallis and Mann-Whitney U tests
Slika 4: Diagram box plot, ki prikazuje vrednosti osnovnih gostot, merjenih v vodi po fazah razkroja. Osamelci in visoki odkloni od mediane nakazujejo veliko variabilnost znotraj posamezne stopnje razgradnje. Slika prikazuje revidirane vrednosti iz Finžgar et al., 2013 in opravljene nove meritve.

Preglednica 4: P (sig.) vrednosti Kruskal-Wallisovega in Mann-Whitneyevega U testa

\begin{tabular}{|c|c|c|c|}
\hline & \multicolumn{2}{|c|}{ Kruskal-Wallis test of decay classes 1-5 / Kruskal-Wallisov test prvih petih stopenj razkroja } \\
\hline & $\begin{array}{c}\text { Absolute density }(\mathrm{Hg}) \\
\text { Absolutna gostota }(\mathrm{Hg})\end{array}$ & $\begin{array}{c}\text { Saturated density }\left(\mathrm{H}_{2} \mathrm{O}\right) \\
\text { Nasičena gostota }\left(\mathrm{H}_{2} \mathrm{O}\right)\end{array}$ & $\begin{array}{c}\text { Basic density }\left(\mathrm{H}_{2} \mathrm{O}\right) \\
\text { Osnovna gostota }\left(\mathrm{H}_{2} \mathrm{O}\right)\end{array}$ \\
\hline P value. & 0.005 & 0.000 & 0.000 \\
\hline & \multicolumn{2}{|c|}{ Mann-Whitney U test of classes 3 and 4 / Mann-Whitneyev U test faz 3 in 4 } \\
\hline & Absolute density $(\mathrm{Hg})$ & Saturated density $\left(\mathrm{H}_{2} \mathrm{O}\right)$ & Basic density $\left(\mathrm{H}_{2} \mathrm{O}\right)$ \\
Absolutne gostota $(\mathrm{Hg})$ & Nasičena gostota $\left(\mathrm{H}_{2} \mathrm{O}\right)$ & 0.746 \\
\hline P value. & 0.244 & 0.557 & Osnovna gostota $\left(\mathrm{H}_{2} \mathrm{O}\right)$ \\
\hline
\end{tabular}


Table 5: Model age classes for different decay phases from 2001 (Kraigher et al., 2002) and 2012
Preglednica 5: Modelni razredi starosti odmrlih debel v različnih stopnjah razkroja iz leta 2001 (Kraigher et al., 2002) in 2012

\begin{tabular}{|c|c|c|c|}
\multicolumn{2}{c|}{ Model 2001 (Kraigher et al., 2002) } & \multicolumn{2}{c|}{ Model 2012 } \\
\hline $\begin{array}{c}\text { Decay class } \\
\text { Stopnja razgradnje }\end{array}$ & $\begin{array}{c}\text { Age-since-death [years] } \\
\text { Čas od odmrtja [leta] }\end{array}$ & $\begin{array}{c}\text { Decay class } \\
\text { Stopnja razgradnje }\end{array}$ & $\begin{array}{c}\text { Age-since-death [years] } \\
\text { Čas od odmrtja [leta] }\end{array}$ \\
\hline 1 & 8 & 1 & 16 \\
\hline 2 & 12 & 2 & 19 \\
\hline 3 & 17 & 3 & 21 \\
\hline 4 & 24 & 4 & 25 \\
\hline 5 & 35 & 5 & 32 \\
\hline 6 & 51 & 6 & 28 \\
\hline
\end{tabular}

sity (Figure 5) are problematic, because no study using this density definition was found and consequently the comparison of the results is impossible. However, saturated densities are easy to measure on scales such as MSA 323S and results contain fewer measuring and operational errors, since only one weighting of the sample mass is sufficient.

Although the Kruskal-Wallis test showed differences between decay classes means in all measured density definitions, the Man Whitney U test showed no significant difference between decay classes 3 and 4 (Table 4). We explain this with a subjective descriptive determination of decay class, as well as sampling methods. Determining CWD decay class is highly subjective and does not best describe the drilled material, since it is so highly inhomogeneous (Figure 1). Therefore, the purposive sampling (by choosing a sample from the drilled material that would suit the description of the determined decay class) could be used, or the number of samples could be significantly increased. The latter can of course be time and money consuming.

It would be wise to choose the sample for density measurements directly at site.

There is also a possibility to use the descriptive subdivision system of decomposition with less than six stages. Different study groups use 4, 5, 6, even 8 classes of decay, which are determined with various methods. Classes can as well be merged into fewer classes for the analysis purpose (Fraver et al., 2002; Stokland and Siitonen, 2012).

Sample size has significant influence on the measurements accuracy, but is limited by both the MSA 323S specifications and work restrictions in natural forest reserves. Studies have shown that with the decrease of sample volume and increase of uneven sample surface, inaccuracy of the measurements is increasing (Eric-

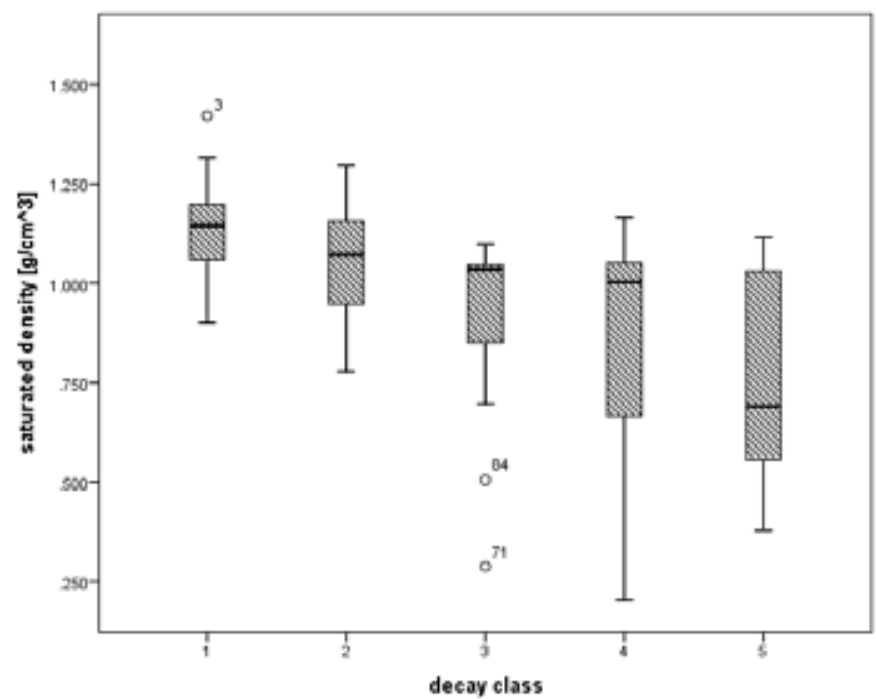

Fig. 5: Box plot diagram showing the saturated values, measured in the water medium by decay class. Both the presence of outliers and high deviations from the median indicate high variability of the decayed samples. New measurements are included, and revised data from Finžgar et al., 2013 are presented.
Slika 5: Diagram box plot, ki prikazuje vrednosti osnovnih gostot, merjenih v vodi po fazah razkroja. Osamelci in visoki odkloni od mediane nakazujejo veliko variabilnost znotraj posamezne stopnje razgradnje. Slika prikazuje revidirane vrednosti iz Finžgar et al., 2013 in opravljene nove meritve. 
son, 1996; Olesen, 1971). Besides, the variability of the results is lower if the samples are larger (Olesen, 1971; Fraver et al., 2002). Flatly sawn samples with volume of $6 \mathrm{~cm}^{3}$ or larger would be ideal. However, as stated before, highly decomposed material (decay class higher than 3) is unsuitable for sawing. MSA 323S allows measurements of samples to around $15-25 \mathrm{~cm}^{3}$, while the Breuil volume-meter is limited to $6 \mathrm{~cm}^{3}$.

It is not possible to compare the results from the mercury measurements with the water measurements, since the used definitions were not the same (Wagenführ, 1966).

Even though measuring absolute densities of decomposed wood in water is impossible, modifications on MSA 323S could be done in order to conduct absolute densities in petroleum (Vintila, 1939). In that case the measurements would have to be calculated on our own, since this modification is not integrated into MSA 323S software. Besides, it might be more time consuming and had never before been used according to our literature search.

During the use of the MSA 323S balance, some technical problems may occur and influence the results. When measuring highly decayed samples (class more than 3), samples can disintegrate or deform when immersed into water, removing surplus water or handling with tweezers. This can lead to volume deformation. During the immersion into water, air bubbles often occur. They should be carefully pierced with a thin object, as they have high influence on specific mass software calculations.

Table 5 and Figure 6 indicate that the initial decay rates obtained by the exponential model from Kraigher et al. (2002) might be too slow. This was also observed on site, where some CWD advanced from decay class 1 to decay class 4 in just 11 years.
Scatter in Figure 6 also shows that the decay rates are extremely uneven. This may be due to different microclimate factors, different fungal decomposition, stage of fungal activity before the death of CWD, high fungal diversity on the selected site and individual factors (Boddy, 2001; Piltaver et al., 2002; Stokland and Siitonen, 2012). Also the expected global climate change in the present and ensuing years will influence the decay (Anderson, 1991).

Models based on dendrochronological determination of age since death are problematical since age determination can only be done in the first 3 decay classes, partially in decay class 4 (Kraigher et al., 2002). Therefore assumptions are made on how the decay proceeds further in decay stages. The results from Table 5 and Figure 6 show not only that it proceeds faster than expected, but also that the exponential function might not be the most suitable function for modelling such process. More research toward optimizing the model should be considered in the future.

\section{CONCLUSIONS}

\section{SKLEPI}

MSA 323S scale (Sartorius, Germany) with YDK01 Density Determination Kit proved to be a fast and efficient method for wood density measurements. However, this method is not a full alternative to the Breuil mercury volume-meter since we cannot measure absolute densities of CWD in water medium. Of course, the ability of measuring densities under several definitions is unnecessary when dealing with the task of CWD decomposition analysis, but it allows us to compare results with older studies that mostly relied on mercury as the medium. Luckily, the usage of basic density as one of the most used definitions (Teodosiu and Bouriaud, 2012; Weggler et al., 2012; Fraver et al., 2002)

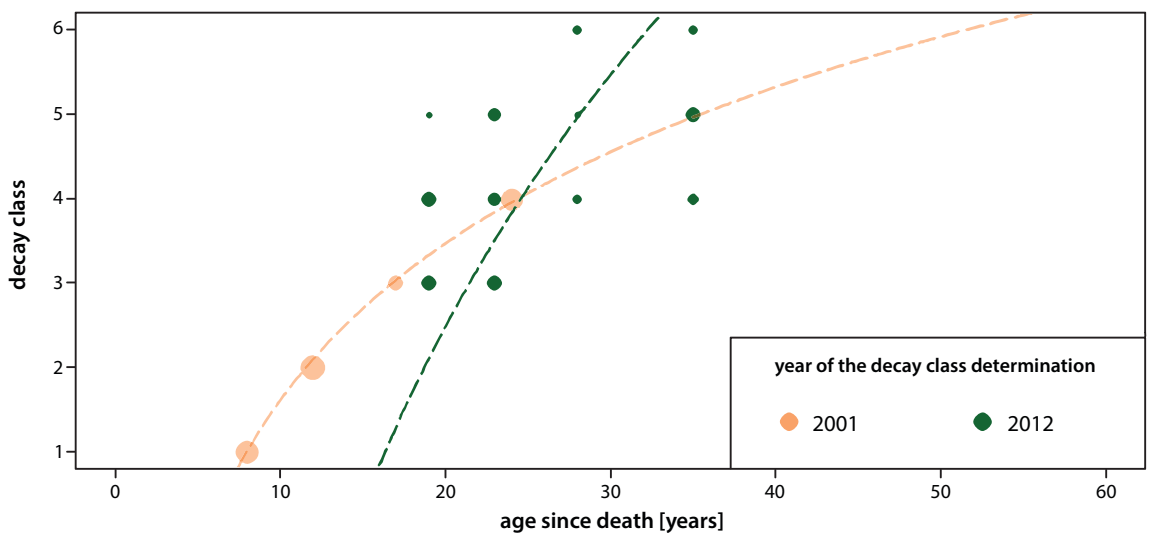

Fig. 6: Scatter plot showing relations between age-since-death and decay class in both initial (2001) research (Kraigher et al., 2002) and after 11 years (2012). The size of dots re-

Slika 6: Diagram ponazarja odvisnost stopnje razkroja od časa odmrtja drevesa, velikost posamezne pike pa število VLO, ki so v modelu zasedli isto vrednost 
is possible in the water medium. For the future standardization of measuring process on MSA 323S scale, studies should focus on measuring larger samples (ca. 6-15 $\mathrm{cm}^{3}$ ), different ways of sampling (drilling, sawing, cutting) and on different sample handling (freezing of samples during transportation, vacuuming) (Kraigher et al., 2002; Fraver et al., 2002; Weggler et al., 2012).

Since measuring densities in water medium based on buoyancy is an old, cost efficient, simple and reliable method, we should not limit ourselves to the use of "the state of the art" measuring devices. This method, even with larger or vacuumed samples, can be executed on practically any laboratory scale with some engineering modifications (Olesen, 1971; Weggler et al., 2012).

\section{POVZETEK}

Rast gozdov je ena izmed redkih oblik skladiščenja ogljika na kopnem. V času do kulminacije letnega prirastka je drevo ponor ogljika. Po kulminaciji sta skladiščenje in sproščanje ogljika nekaj časa $\mathrm{v}$ ravnovesju, nato pa se $\mathrm{z}$ razgradnjo tkiv drevesa ogljik sprošča nazaj v atmosfero (Nijnik, 2010). Razumevanje dinamike razkroja lesa je torej nujno za razumevanje dinamike ogljika. Veliki lesni ostanki (VLO oz. CWD, coarse woody debris) v klimaksnih gozdnih združbah pripomorejo k temu razumevanju, saj so prikaz razkroja lesa kot poteka v naravi. Za ugotavljanje hitrosti razkroja VLO je potrebno merjenje gostote $\mathrm{v}$ določenih časovnih razmikih. Merjenje gostote lesa otežujejo številne definicije gostot. Navadno merimo absolutno gostoto (masa absolutno suhega lesa na volumen absolutno suhega lesa), osnovno gostoto (masa absolutno suhega lesa na volumen napojenega lesa) in zeleno gostoto (masa svežega lesa na volumen svežega lesa). Obstajajo pa tudi druge definicije gostote (Wagenführ, 1996; Torelli, 1998).

Raziskave so pokazale, da naj bi bila najustreznejša definicija gostote osnovna gostota (Olesen, 1971; Usta, 2003), saj naj bi rezultati najmanj variirali, če zagotovimo ustrezno napojitev vzorcev $\mathrm{v}$ deionizirani vodi (Olesen, 1971).

V Sloveniji se je pri raziskavah pomena VLO za dinamiko ogljika in biodiverziteto merila absolutna gostota (Kraigher in sod., 2002). Slednjo so na Gozdarskem inštitutu Slovenije doslej določali z Breuilovim živosrebrnim volumometrom. Merjenje gostot v živem srebru je problematično zaradi zahtev Evropske unije po umiku te nevarne snovi iz človekovega okolja. Z zadnjim sprejetim amandmajem št. 847/2012 pa je prodajo merilnih naprav z živim srebrom prepovedala tudi v strokovne in industrijske namene. Amandma bo začel veljati z dnem 10. 4. 2014 (Uredba št. 847/2012).

Namen raziskave je ugotavljanje metodologije merjenja gostot VLO v vodnem mediju, z namenom kasnejše standardizacije postopka. Postopen prehod iz živosrebrnega v vodni medij je namreč ne le zaradi uredb Evropske unije, temveč tudi zaradi človekovega zdravja nujen. Ker se je v Sloveniji pri raziskavah pomena VLO za dinamiko ogljika in biodiverziteto merila absolutna gostota, določena z Breuilovim živosrebrnim volumometrom (Kraigher in sod., 2002), smo torej želeli ugotoviti, ali lahko z merjenjem gostote VLO v vodnem mediju dosežemo primerljive rezultate. Del raziskave je že bil objavljen v članku z naslovom Ugotavljanje gostot velikih lesnih ostankov bukve (Fagus sylvatica L.) iz pragozdnega rezervata Rajhenavski Rog (Finžgar in sod. 2013). Tu pa so predstavljeni revidirani rezultati, nove meritve in rezultati merjenja vsebnosti vlage v vzorcih.

Vzorce za raziskavo smo izvrtali na južnem robu pragozdnegarezervata Rajhenavski Rog naraziskovalniploskvi, kjer so VLO raziskovali leta 2002 v okviru projekta NAT-MAN (Ódor in sod., 2006; Kraigher in sod., 2002). Vzorce smo pridobivali z vrtanjem (vzorčila sta Domen Finžgar in Matej Rupel) v velike lesne ostanke bukve (Fagus sylvatica L.) (ležeče in stoječe). Izbrani VLO so bili večinoma enaki kot $\mathrm{v}$ raziskavi leta 2002. Takrat so bili ustrezno označeni in opisani (Kraigher in sod., 2002). Dodatno je bil vključen en VLO izmed več na novo padlih VLO. Iz izvrtkov smo naključno izbrali 207 vzorcev za meritve gostot z živim srebrom in 163 vzorcev za meritve z vodo. Vzorce smo porazdelili v stopnje razgradnje 1 do 5 .

Merili smo absolutno gostoto $\mathrm{v}$ živem srebru in osnovno gostoto ter nasičeno (nasičena masa vzorca na nasičen volumen vzorca) gostoto v vodi. Ker je bila tehtnica MSA 323S z dodatkom za merjenje gostot (Sartorius, Nemčija) v raziskavah Gozdarskega inštituta Slovenije uporabljena prvič, smo opravili še testno merjenje osmih testnih vzorcev lesa bukve $\mathrm{z}$ znanimi dimenzijami $(0,7 \times 1,0 \times 3,0 \mathrm{~cm})$.

Rezultati so gostote, izmerjene tako z živosrebrnim kot z vodnim volumometrom in vsebnost vlage v vzorcih.

Povprečne vrednosti različnih gostot so predstavljene v preglednici 3. Vrednosti meritev so primerljivega velikostnega razreda kot tiste iz leta 2002 (Kraigher in sod., 2002), vrednost standardnega odklona je višja. Velja preučiti možnosti ustreznejšega odvzema vzorcev in njihovega prevoza na merilno mesto.

Iz rezultatov smo izključili meritve vzorcev prve in druge stopnje razgradnje v živosrebrnem mediju zaradi suma, da so jim bile stopnje pred revizijo 9. 7. 2013 napačno ocenjene (preglednica 3 ). 
Gostota lesa z razkrojem pada (Stokland in Siitonen, 2012), kar rezultati, pridobljeni v tej raziskavi, potrjujejo (preglednica 3, sliki 4 in 5), razen pri stopnji pet, ki je nenavadno velika. Nasičene gostote doslej v znanstvenih razpravah o VLO nismo zasledili in je zato razprava o njeni uporabi težavna, čeravno je za merjenje na naši tehtnici MSA 323S ta gostota najenostavnejša. Stopnji faz razkroja 3 in 4 sta si bili tako v absolutni kot tudi osnovni gostoti podobni (preglednica 4), kar je najverjetneje problem uvrščanja posameznega VLO $\mathrm{v}$ določeno stopnjo razgradnje in načina vzorčenja.

Kakršnekoli statistične primerjave meritev z živim srebrom in tistih, opravljenih z vodo, niso ustrezne, saj so bile merjene različne gostote (Wagenführ, 1966). Merjenje absolutne gostote razkrojenega lesa v vodnem mediju ni bilo mogoče.

Pri spoznavanju tehtnice MSA 323S in dodatka YDK01 smo odkrili nekaj fenomenov, ki vplivajo na rezultate. Pri višjih fazah razkroja vzorcev lesa lahko med nasičenjem v vodi in prenašanjem na merilno napravo povzročimo razpad vzorcev ali deformacijo njihovega volumna. Zato moramo med merjenem z njimi ravnati skrajno previdno, poskrbeti je treba za odstranitev odvečne vode s površine vzorca. Med merjenjem z YDK01 pogosto nastajajo zračni mehurčki, ki jih moramo sproti predreti, saj nepredrti močno vplivajo na rezultate.

Merilna tehtnica Sartorius MSA 323S z dodatkom za merjenje gostot YDK01 se je izkazala za izjemno hitro in preprosto metodo merjenja gostot lesa. Alternativa živosrebrni metodi pa ta vendarle ni, saj ne omogoča merjenja vseh vrst gostot, ki jih lahko obravnavamo v raziskavah. Za namen ugotavljanja gostot VLO obravnavanje vseh vrst gostot seveda ni potrebno, potrebno pa je poenotenje zavoljo statistične primerljivosti rezultatov v različnih časovnih obdobjih.

Po pričakovanjih sta nasičena in osnovna gostota pokazali trend padanja gostot. Pri absolutni gostoti nam tega ni uspelo dokazati. Tehtnica Sartorius se je izkazala za zanesljivo in hitro metodo merjenja gostot v vodi, ki pa jo bo treba še optimizirati.

Revizija faz razkroja po enajstih letih od raziskave Kraigher et al. (2002) nakazuje hitrejši razkroj VLO od takrat predvidevanega (slika 6 in preglednica 5).

\section{ZAHVALA}

\section{Acknowledgment}

We sincerely thank Iztok Sinjur, Nejc Thaler, Daniel Žlindra and Magda Špenko for their help with the density measurements, and to Dr. Andrej Rozman for the introduction to R programming.
This research was co-financed under the L4-4318 project by the Slovenian Research Agency and the Ministry for Agriculture and the Environment. Release of the paper was supported in part by a grant from Pahernikova ustanova.

\section{REFERENCES}

Anderson J.M. 1991. The Effects of Climate Change on Decomposition Processes in Grassland and Coniferous Forests. Ecological Applications, 1, 3: 326-347.

Bončina A. 1999. Stand Dynamics of the Virgin Forest Rajhenavski Rog (Slovenia) During the Past Century. In: Virgin Forests and Forest Reserves in Central and East European Countries. Diaci J. (ed.). Ljubljana, Biotechnical Faculty, Department of Forestry and Renewable Forest Resources: 95-110.

Boddy L. 2001. Fungal community ecology and decomposition processes: From standing tree to complete decay of coarse woody debris. Ecological Bulletins, 49: 43-56.

Derbiš M. 1957. Pragozd v Kočevskem Rogu. Diplomsko delo. Ljubljana, Biotechnical Faculty, Department of Forestry and Renewable Forest Resources: 46 str.

Ericson B. 1966. Determination of Basic Density in Small Wood Samples. Department of Forest Yield Research: Research Notes, 9: $1-34$.

Finžgar D., Rupel M., Humar M., Kraigher H. 2013. Ugotavljanje gostot velikih lesnih ostankov bukve (Fagus sylvatica L.) iz pragozdnega rezervata Rajhenavski Rog. Les, 65, 1-2: 41-48.

Fraver S., Wagner G.R., Day M. 2002. Dynamics of coarse woody debris following gap harvesting in the Acadian forest of central Maine U.S.A.. Canadian Journal of Forest Research, 32, 12: 20942105.

Hartman T. 1999. Hundred Years of Virgin Forest Conservation in Slovenia. In: Virgin Forests and Forest Reserves in Central and East European Countries. Diaci J. (ed.). Ljubljana, Biotechnical Faculty, Department of Forestry and Renewable Forest Resources: 111-120.

Heinrichs J.F., Lassen L.E. 1970. Improved Technique for Determining the Volume of Irregularly Shaped Wood Blocks. Forest Products Jurnal, 20, 4: 24.

Holz D., Plickat H. 1961. Über die Bestimmung der Darrdichte an kleinen Holzproben. Holz als Roh- und Werkstoff, 19, 2: 55-60.

Jonsson G., Siitonen J. 2012. Dead wood and sustainable forest management. In: Biodiversity in Dead Wood. Stokland J.N. (ed.). New York, Cambridge University Press: 302-337.

Kraigher H., Jurc D., Kalan P., Kutnar L., Levanič T., Rupel M., Smolej I. 2002. Beech Coarse Woody Debris Characteristics in Two Virgin Forest Reserves in Southern Slovenia. Zbornik gozdarstva in lesarstva, 69: 91-134.

Nijnik M. 2010. Carbon Capture and Storage in Forests. In: Carbon Capture, Sequestration and Storage. Harrison RM (ed.), Hester RE (ed.). Cambridge, RSC Publishing: 203-239.

Ódor P., Heilmann-Clausen J., Christensen M., Aude E., van Dort K. W., Piltaveer A., Siller I., Veerkamp M. T., Walleyn R., Standova T., van Hees A. F. M., Kosec J., Matočec N., Kraigher H., Grebenc T. 2006. Diversity of dead wood inhabiting fungi and bryophytes in semi-natural beech forests in Europe. Biological Conservation, 131: 58-71.

Olesen P.0. 1971. The Water Displacement Method. Forest Tree Improvement, 3: 3-23.

Piltaver A., Matočec N., Kosec J., Jurc D.2002. Macrofungi on Beech Dead Wood in the Slovenian Forest Reserves Rajhenavski Rog and Krokar. Zbornik gozdarstva in lesarstva. 69: 171-196. 
Stokland J.N., Siitonen J. 2012. Mortality factors and decay succession. In: Biodiversity in Dead Wood. Stokland J.N. (ed.), New York, Cambridge University Press: 302-337.

Teodosiu M., Bouriaud B.O. 2012. Deadwood specific density and its influental factors: A case study from a pure Norway spruce oldgrowth forest in the Eastern Carpathians. Forest Ecology and Management, 283: 77-85.

Torelli N. 1998. Gostota in relativna gostota lesa. LES, 50, 3: 52-54.

Usta I. 2003. Comparative Study of Wood Density by Specific Amount of Void

Volume (Porosity). Turkish Journal of Agriculture and Forestry, 27: 1-6.

Vintila E. 1939. Untersuchungen über Raumgewicht und Schwindma $\beta$ von Früh- und Spätholz bei Nadelhölzern. Holz als Roh- und Werkstoff, 2, 10: 345-357.

Von Wendel K. 1962. Hydrostatische Verfahren zur Bestimmung der Rohdichte von Holzproben. Holz als Roh- und Werkstoff, 20, 9: 360-364.
Wagenführ R. 1996. Holzatlas. Leipzig, Fachbuchverlag Leipzig, Leipzig: 688 p.

Walker C.F. J. 2006. Primary Wood Processing. Dordrecht, Springer: $602 \mathrm{p}$.

Weggler K., Dobbertin M., Jüngling E., Kaufmann E., Thürig E. 2012. Dead wood volume to dead wood carbon: the issue of conversion. European Journal of Forest Research, 131, 5: 1423-1438.

Williamson G. B., Wiemann M. C. 2010. Measuring wood specific gravity... Correctly. American Journal of Botany, 97, 3: 519-542.

UREDBA (ES) št. 1907/2006 o registraciji, evalvaciji, avtorizaciji in omejevanju kemikalij (REACH) (2006) Uradni list Evropske unije L 136: 3-280.

UREDBA KOMISIJE (EU) št. 847/2012 o spremembi Priloge XVII k Uredbi (ES) št. 1907/2006 Evropskega parlamenta in Sveta o registraciji, evalvaciji, avtorizaciji in omejevanju kemikalij (REA$\mathrm{CH})$ glede živega srebra (2012) Uradni list Evropske unije L 253: 1-4. 